\title{
APLIKASI MODEL ROLE PLAYING SEBAGAI UPAYA PEMBELAJARAN NILAI DALAM PENDIDIKAN IPS SD/MI
}

\author{
Indah Aminatuz Zuhriyah
}

\author{
Staf Pengajar pada PGMI Fakultas Tarbiyah UIN Malang
}

\begin{abstract}
Value is a conviction or believes that become the basic for a person or a group of person to choose their action, or appraise something meaningful or something unmeaning for their live. This interpretation means that value is a characteristic attributed to something related to subject (human as the provider of value). Social values in social science education in elementary school (SD/MI) can be applied trough role playing. Role playing is learning processes in which the students do something have done by other people. That other people maybe is a president, ministry, prominent figure of society, law official, teachers, the owner of other professions, officials, or even the ordinary people. The important thing from this learning process is that students try to think, feel the emotion, and act not as their own self but as others. By occupy and inspire the role, students are going to understand why such kind of action should be done, what kind of value underlying that consideration, and how the object people face that kind of situation.
\end{abstract}

Keyword: value education, role playing, social science.

\section{A. Pendahuluan}

Belajar merupakan kegiatan aktif siswa dalam membangun makna atau pemahaman terhadap suatu konsep, sehingga dalam proses pembelajaran siswa merupakan sentral kegiatan, pelaku utama dan guru hanya menciptakan suasana yang dapat mendorong timbulnya motivasi belajar pada siswa. Implementasi KTSP dalam proses pembelajaran menuntut adanya reorientasi pembelajaran yang konvensional. Reorientasi tidak hanya sebatas istilah "teaching" menjadi "learning", namun harus sampai pada operasional pelaksanaan pembelajaran.

Untuk itu, proses pembelajaran harus mengacu pada beberapa prinsip, yaitu: berpusat pada siswa, belajar dengan melakukan, mengembangakan kemampuan sosial, mengembangkan keingintahuan, imajinasi dan fitrah ber-Tuhan, mengembangkan keterampilan pemecahan masalah, mengembangkan kreatifitas siswa, mengembangkan kemampuan menggunakan ilmu dan teknologi, menumbuhkan kesadaran sebagai warga negara yang baik, belajar sepanjang hayat, dan perpaduan kompetisi, kerjasama dan solidaritas. Dalam kedudukan sebagai perancang dan pengembang kegiatan belajar, guru harus mampu menerapkan dan mengembangkan prinsip-prinsip belajar dalam bentuk kegiatan belajar. Kegiatan-kebiatan belajar yang memungkinkan siswa aktif 
mengembangkan sikap, nilai, dan moral dalam dirinya dapat digunakan model bermain peran (role playing).

Bermain peran adalah suatu proses belajar di mana siswa melakukan sesuatu yang dilakukan orang lain. Orang lain itu mungkin seorang presiden, menteri, tokoh masyarakat, pejabat hukum, dosen/guru, pemegang profesi, jabatan, atau bahkan anggota masyarakat biasa. Hal yang penting dalam proses belajar ini adalah siswa mencoba berfikir, berperasaan, dan bertindak bukan sebagai dirinya tetapi sebagai orang lain. Dengan memegang dan menghayati peran tersebut, siswa akan dapat memahami mengapa suatu tindakan harus dilakukan, nilai apa yang mendasari pertimbangan tindakan tersebut, dan bagaimana orang yang dilakoni itu menghadapi situasi tertentu.

Proses pengembangan kepribadian yang demikian membantu pula terhadap siswa yang kurang berminat menjadi lebih bergairah dalam belajar ilmu-ilmu sosial. Mereka yang kurang berminat akan dibantu mereka yang berminat tinggi dan juga memiliki kemampuan menerapkan apa yang sudah dipelajari. Dalam situasi belajar yang demikian maka di antara siswa itu sendiri terbina nilai lain seperti; nilai gotong royong, saling percaya, kepedulian social antar anggota, dan kesediaan menerima dan member.

Suasana belajar yang lebih rileks dan mengandalkan kepercayaan kepada setiap individu/kelompok siswa haruslah menjadi dasar bagi guru dalam mengembangkan strategi mengajar. Terlebih-lebih suasana belajar yang berhubungan dengan kegiatan di luar, sementara yang bersangkutan masih menjadi siswa seperti penerapan nilai dalam prilaku. Suasana yang demikian akan sangat menentukan keberhasilan pencapaian tujuan pembelajaran afektif dalam pendidikan ilmu pengetahuan sosial.

\section{B. Pengertian Pendidikan Nilai}

Mengkaji masalah nilai, memang bukan sesuatu yang mudah, seperti sifat dan corak berpikir kefilsafatan, nilai sulit diukur. Menurut Sumarna (2005) ia bersifat relative subjektif. Sebab setiap individu, masyarakat, ideologi dan setiap agama memiliki nilai sendiri yang kadang bukan saja berbeda dengan nilai lain, tetapi sering kali di antara nilai itu ditemukan adanya pertentangan. Namun dengan demikian, mendiskusikan nilai bukan sesuatu yang sulit untuk dibangun.

Sebagaimana Milton Roceach dan James Bank dalam Lubis (2008) dapat memberikan pengertian tentang nilai, bahwa nilai adalah suatu tipe kepercayaan yang berada dalam ruang lingkup sistem kepercayaan yang berada dalam ruang lingkup sistem kepercayaan, di mana seseorang harus bertindak atau menghindari suatu tindakan, atau mengenai sesuatu yang pantas atau tidak pantas dikerjakan, dimiliki dan dipercaya. Dalam pengertian yang lain, sebagaimana tertuang dalam A value, says Webster, is 
"a principle, standard or quality regarded as worthwhile or desirable," yakni nilai adalah prinsip, standar atau kualitas yang dipandang bermanfaat atau sangat diperlukan. Nilai ialah "suatu keyakinan atau kepercayaan yang menjadi dasar bagi seseorang atau sekolompok orang untuk memilih tindakannya, atau menilai suatu yang bermakna atau tidak bermakna bagi kehidupannya". Pengertian ini berarti bahwa nilai itu merupakan sifat yang melekat pada sesuatu yang telah berhubungan dengan subjek (manusia pemberi nilai).

Sementara Gazalba (dalam Lubis, 2008) mengartikan nilai adalah sesuatu yang bersifat abstrak dan ideal. Nilai bukan benda konkret, bukan fakta, tidak hanya sekedar soal penghayatan yang dikehendaki atau tidak dikehendaki, yang tidak disenangi atau tidak disenangi. Nilai itu terletak antara hubungan antara subjek penilai dengan objek. Garam, Emas, Tuhan itu tidak bernilai bila tidak ada subjek yang menilai. Garam itu menjadi berarti setelah ada oang yang membutuhkan, Emas itu menjadi berharga setelah ada oang ang mencari perhiasan, dan Tuhan itu menjadi berarti setelah ada makhluk ang membutuhkan, pada saat ia sendirian, maka hanya Tuhan hanya berarti bagi diriNya. Tetapi nilai juga terletak pada barang (objek) itu. Nilai ke-Tuhanan karena dalam zat Tuhan terdapat suatu yang sangat berharga bagi manusia, dan dalam logam emas terdapat zat yang tidak lapuk, antikarat, dan jenis-jenis keindahan lainnya yang sangat berharga bagi manusia.

Berdasarkan beberapa pengertian diatas, bisa digariskan bahwasanya nilai merupakan esensi yang melekat pada sesuatu yang sangat berarti bagi kehidupan manusia. Esensi itu sendiri belum berarti sebelum dibutuhkan manusia, tetapi bukan berarti adanya esensi itu karena adanya manusia yang membutuhkan. Hanya saja kebermaknaan esensi tersebut semakin meningkat sesuai dengan peningkatan daya tangkap pemaknaan manusia itu sendiri. Hakikat kehidupan social kemasyarakatan adalah untuk perdamaian. Perdamaian hidup merupakan esensi kehidupan manusia. Esensi tidak akan hilang walaupun semakin tinggi selama manusia mampu memberikan makna perdamaian itu.

\section{Konsep Dasar Model Role Playing \\ 1. Pengertian Role Playing (Bermain Peran)}

Role playing (bermain peran) adalah salah satu bentuk permainan pendidikan (e-ducaticnal games) yang dipakai untuk menjelaskan perasaan, sikap, tingkah laku dan nilai, dengan tujuan untuk menghayati perasaan, sudut pandangan dan cara berpikir orang lain (membayangkan diri sendiri seperti dalam keadaan orang lain) (Hasan, 1996).

Dalam kegiatan bermain peran, pembelajaran disajikan pada situasi yang nyata kepada siswa dan memilih pemain untuk masing 
masing karakter kemudian siswa mengembangkan dialog dan tindakantindakan untuk mencocokan pandangan-pandangan situasi dan karakter yang mereka mainkan (Davis dalam Killen, 1998). Sering kali bermain peran dirancang untuk membantu siswa memahami perasaan dan pandangan yang lain melalui bertindak diluar situasi yang mana terdapat sebuah konflik atau dilema mereka menyediakan kesempatan untuk siswa supaya terlibat lebih jauh dalam memikirkan tentang bagaimana mereka akan bereaksi dalam situasi dunia nyata.

Untuk menciptakan bermain peran yang berhasil, siswa hendaknya mengasimilasi informasi-informasi yang disediakan tentang perannya dan kemudian tindakan di luar peran yang dirancang sesuai dengan interpretasi mereka tentang bagaimana karakter yang harus mereka perankan dalam situasi tersebut. Biasanya bermain peran melibatkan dua atau tiga siswa saja. Mayoritas siswa mengamati dan menganalisis interaksi antar pemeran. Sedangkan guru merencanakan, menstrukturkan, memfasilitasi dan memonitor permainan tersebut kemudian membimbing untuk menindaklanjuti pembahasan tersebut. Menurut Dahlan (1990) Masalah-masalah yang dipecahkan melalui bermain peran berbeda dengan masalah-masalah yang dipecahkan melalui tanya jawab, discovery, inquiry, atau diskusi kelas. Bermain peran diarahkan pada pemecahan masalah-masalah yang menyangkut hubungan antar manusia (human relation problems) terutama yang berkaitan dengan kehidupan siswa.

Bermain peran menunjukan bagaimana cara guru mengajarkan sejarah (umpamanya) dan sosial selama ini ternyata harus selalu sesuai dengan akademis, teoritis dan tidak memunculkan kemampuan individu. Sehingga kekuatan utama pendekatan-pendekatan tersebut adalah bahwa mereka terlibat secara pikiran dan badan pada saat yang sama dengan zaman yang berbeda ketika mereka mengekspresikan imajinasinya, memberikan masukan bahwa bermain peran mengurangi kepasifan kelas atau meningkatkan daya ingat, mengarah pada tingkat pemahaman yang lebih tinggi mengenai konsep-konsep dan memotivasi meningkatkan verbalisme.

Melalui bermain peran, para siswa mencoba mengeksploitasi masalah-masalah hubungan antar manusia dengan cara memperagakannya. Hasil peragaan atau pemeranan tersebut kemudian didiskusikan dalam kelas; sehingga secara bersama-sama mereka dapat mengeksplorasi perasaanperasaan, sikap-sikap, nilai-nilai, dan berbagai strategi pemecahan masalah.

proses belajar yang dinamakan bermain peran menuntut kualitas tertentu pada siswa. Siswa diharapkan mampu menghayati tokoh atau posisi yang dikehendaki. Sebagaimana menurut Hasan (1996:266) "Keberhasilan siswa dalam menghayati peran itu akan menentukan apakah proses pemahaman, penghargaan, dan identifikasi diri terhadap nilai berkembang". 
Sebagai suatu model mengajar, bermain peran berakar pada dimensi pribadi, dan dimensi sosial kependidikan. Dari dimensi pribadi, model ini berusaha membuat para siswa menemukan makna dari lingkungan sosial yang bermanfaat bagi dirinya. Melalui model ini para siswa diajak untuk belajar memecahkan dilema-dilema pribadi yang mengukungnya dengan bantuan kelompok sosial yang anggota-anggotanya adalah teman-teman rnereka sendiri. Dengan kata lain, dilihat dari dimensi pribadi, model ini berupaya membantu individu melalui proses kelompok sosial.

Dilihat dari dimensi sosial, model ini memberikan kesempatan para siswa untuk bekerja sama dalam menganalisa situasi-situasi sosial, terutama masalah-masalah hubungan antar pribadi-pribadi siswa. Pemecahan masalah tersebut dilakukan secara demokratis. Jadi melalui model ini mereka juga dilatih untuk menjunjung tinggi nilai-nilai demokrasi (Dahlan, 1990,123 -124).

\section{Dasar Implementasi Role Playing (Bermain Peran) dalam Proses Pembelajaran}

Ada empat asumsi yang mendasari model pembelajaran ini yang membuat kedudukannya sejajar dengan model-model pembelajaran lainnya. Keempat asumsi tersebut menurut Hasan (1996) adalah:

Pertama, secara implisit bermain peran mendukung suatu situasi belajar berdasarkan pengalaman dengan menekankan dimensi "di sini dan kini" (here and now) sebagai isi pengajaran. Model ini percaya adalah suatu hal yang mungkin sekelompok siswa menciptakan analogi-anologi mengenai situasi-situasi kehidupan nyata. Terhadap anologi-anologi tersebut yang diwujudkan dalam bermain peran para siswa dapat menampilkan responrespon emosional secara khas dan sejati sambil belajar dari respon-respon orang lain.

Kedua, bermain peran memberikan kemungkinan kepada para siswa untuk mengungkapkan perasaan-perasaanya yang tak dapat mereka kenali tanpa bercermin kepada orang lain. Mengungkapkan perasaan untuk mengurangi beban emosional (dikenali dengan cathersis) merupakan tujuan yang sangat esensial dalam psikodrama suatu variasi dari bermain peran tetapi lebih menekankan pada. aspek-aspek therapentik. Namun ada perbedaan penekanan antara bermain peran dalam konteks PBM dengan psikodrama dalam konteks psikoterapi. Bermain peran dalam konteks PBM memandang bahwa baik diskusi setelah pemeranan maupun pemeranan itu sendiri merupakan aktivitas sentral sedangkan dalam psikodrama, pemeranan dan keterlibatan emosional pengamat itulah yang esensial. Diskusi dan analisis peran, usai peran dimainkan, agak kurang dipentingkan dalam psikodrama. Perbedaan lain bobot emosional dalam psikodrama lebih ditonjolkan daripada bobot intelektual, sedangkan dalam bermain peran keduanya sama pentingnya. 
Ketiga, model ini mengasumsikan bahwa emosi dan ide-ide dapat diangkat ke taraf kesadaran untuk kemudian ditingkatkan melalui proses kelompok. Pemecahan tidak selamanya datang dari orang tertentu (misalnya guru), melainkan dapat saja muncul dari reaksi orang lain terhadap masalah ymg tengah diperankan. Dengan demikian, individu dapat belajar dari pengalaman orang lain tentang cara memecahkan masalah yang pada gilirannya dapat ia manfaatkan untuk lebih mengembangkan dirinya. Oleh sebab itu model mengajar ini berusaha untuk mengurangi peran guru yang terlampau menonjol dalam pengajaran tradisional yang cenderung membiarkan para siswa menjadi pendengar dan pemirsa setia. Model mengajar ini mendorong siswa untuk turut aktif dalam pemecahan masalah seraya menyimak secara seksama bagaimana orang lain berbicara tentang masalah yang tengah dihadapi.

Keempat, model pembelajaran ini mengasumsikan bahwa prosesproses psikologis yang tersembunyi (covert) berupa sikap-sikap nilai-nilai, perasaan-perasaan dan sistem keyakinan dapat diangkat ke taraf kesadaran melalui kombinasi pemeranan secara spontan dan analisisnya. Dengan cara itu individu dapat menguji sejauh mana sikap-sikapnya relevan dengan sikap orang lain, apakah sikap itu perlu dipertahankan atau diubah. Tanpa kehadiran orang lain, akan menjadi sulit bagi individu untuk melakukan evaluasi yang demikian.

\section{Tujuan Penggunaan Model Role Playing (Bermain Peran)}

Tujuan utama penggunaan model role playing (bermain peran) menurut Dahlan (1990) sebagai berikut:

1) Untuk memotivasi siswa, khususnya ketika memberikan sebuah unit pelajaran baru.

2) Untuk mengakhiri (penyampaian) beberapa unit pelajaran dan membantu siswa untuk mengkonsolidasikan pembelajaran mereka.

3) Memberikan kesempatan kepada siswa untuk mengekplorasi situasi historis atau kontemporer di mana mereka mengalami emosi, perbedaan pendapat, pembiasan, dan permasalahan-permasalahan dalam lingkungan kehidupan sosial anak.

4) Membuat siswa sadar akan adanya perbedaan pendapat dan konsekuensinya.

5) Membuat siswa sadar akan sikap dan perasaan orang dalam suatu situasi serta kepekaan mereka terhadap perasaan orang lain.

6) Menarik siswa untuk bertanya.

7) Membantu siswa untuk memberikan penilaian dan pemahaman konsekuensi tindakan penilaian tersebut.

8) Untuk mengembangkan kemampuan komunikasi siswa.

9) Untuk mengajarkan dasar-dasar hubungan manusia.

10) Untuk mengembangkan kemampuan kewarganegaraan.

11) Membantu siswa untuk menanggulangi konflik yang terjadi di 
kelas atau mungkin yang mereka temukan di tempat lain.

12) Melatih siswa untuk berperan aktif dalam kehidupan nyata dan menghadapi permasalahan-permasalahan dunia.

\section{Beberapa Keterbatasan Model Role Playing (Bermain Peran)}

Tidak satu pun metode yang benar-benar tepat dan tidak memiliki kelemahan dalam pembelajaran, demikian halnya dengan metode bermain peran yang juga memiliki keterbatasan dan kelemahan, adapun keterbatasan dan kelemahan yang dimaksud seperti yang diungkapkan oleh Killen (1998) adalah sebagai berikut:

1) Bermain peran hanya akan berjalan baik jika suasana kelasnya mendukung.

2) Siswa mengalami kesulitan dalam bermain peran apalagi jika mereka tidak memahami dengan baik apa yang seharusnya mereka lakukan.

3) Bermain peran tidak selalu berjalan lancar sesuai harapan, tapi mungkin saja macet atau berhenti pada keadaan yang tidak diharapkan. Kadang-kadang hal ini juga menimbulkan pertentangan dengan apa yang diharapkan.

4) Bermain peran bisa memakan waktu yang banyak.

5) Siswa yang tidak mempunyai kesiapan baik untuk bermain peran mungkin mereka tidak melakukannya dengan serius, mereka cenderung asal-asalan, menertawakan yang lain, dan pada umumnya mereka menganggap hal tersebut sebagai lelucon.

6) Agar bermain peran ini berjalan dengan baik, dibutuhkan sekelompok siswa yang sensitif, imajinatif, berwawasan luas dan terbuka, saling memahami satu sama lain, agar mereka menyenangi peran tersebut.

Beberapa permasalahan lain yang sering muncul menurut Van Ments dalam (Killen, 1998) a dalah:

(1) Beberapa siswa kadang enggan untuk berpartisipasi.

(2) Seringkali terjadi kesulitan untuk membuat bermain peran itu nampak relevan untuk semua siswa.

(3) Beberapa siswa tidak dapat memainkan peran mereka dengan kredibel, dan bisa saja mengubah pesan yang disampaikan.

(4) Memberi penjelasan dan penegasan akan sangat memakan waktu yang lama.

(5) Penegasan sangat penting, tetapi mungkin tidak disimak dengan serius oleh siswa.

\section{Langkah-Langkah Aplikasi Model Role Playing}

Untuk menghindari kekakuan dalam pela ksanaannya, maka perlu adanya langkah-langkah yang harus dipahami terlebih dahulu. 
Langkah-langkah ini menurut Dahlan (1990) sebagai berikut:

1) Langkah pertama: Identifikasi masalah dengan cara memotivasi para peserta didik

Pada awalnya kegiatan ini dapat diangkat dari kehidupan anak di sekitarnya, sehingga siswa tersebut akan muncul suatu imajinasi yang akan mendoronguntuk ingin tahu, dan muncul pertanyaan apa?, bagaimana?, mengapa?. Ada beberapa permasalahan yang dapat diangkat untuk dipertimbangkan dalam memotivasi siswa. Diantaranya; 1) actual hangat, 2) langsung menyangkut kehidupan para siswa, 3) menarik dan merangsang siswa, dan 4) problematik dan memungkinkan berbagai alternatif.

\section{2) Langkah kedua: Memilih peran}

Pada tahapan ini guru harus mampu memilih siswa sebagai peran yang akan dilakonkan sesuai dengan karakter tokoh yang diperankannya. Contoh sebagai tokoh Pangeran diponegoro, Sukarno, Moh. Hatta, dan sebagainya. Dalam pemilihan peran ini memang tidak semua terpilih sebagai peran tokoh, tetapi ada pula yang menjadi peran pembantu untuk pendukung proses pembelajaran. untuk pemilihan ini guru tidak bias menunjuk sembarangan melainkan diajukan terlebih dahulu kepada siswa, siapa yang sanggup untuk menjadi tokoh atau peran dalam cerita. Baru apabila ada kesulitan, guru menentukan dan membimbing sesuai dengan tujuan pembelajaran yang akan dicapai.

\section{3) Langkah ketiga: Menyiapkan sebagai pengamat dalam proses pembelajaran}

Pengamat ini adalah siswa-siswa yang belum menjadi tokoh yang berperan dalam pembelajaran. namun dalam gilirannya siswa yang menjadi pengamat, akan menjadi peran tokoh, karena pada saat giliran pertama kemungkinan ada peran yang belum dapat tampil (action) sebagaimana karakter tokohnya. Pengamat ini tugasnya mengamati proses pembelajaran yang menampilkan tokoh-tokoh yang diperankan oleh temannya. Setelah mereka menyaksikan, akan mengadakan diskusi, apakah dalam proses pembelajaran tadi sesuai dengan alur cerita atau belum, dan peran mana yang belum selesai dengan karakter tokohnya.

\section{4) Langkah keempat: Menyusun skenario pembelajaran}

Pada tahapan ini, menyusun skenario untuk masing-masing peran dan dibuat narasinya. Begitu pula untuk adegan dipersiapkan, kapan mulainya, apa perlengkapannya, dan bagaimana pentas (action).

\section{5) Langkah kelima: Pemeranan}

Pada tahapan ini, siswa melaksanakan pemeranan sebagaimana yang telah direncanakan. Pada permulaan ini kemungkinan timbul kekakuan tingkah mereka karena masih perlu penyesuaian situasi dan 
kondisi. Dan kemungkinan ada pembicaraan yang menyimpang dari skenario. Proses ini akan terfjadi, dan para pengamat pun akan mengetahui kelemahan-kelemahan rekannya, dari kelemahan ini maka akan timbul peran mana yang kurang cocok memerankan yang ditokohinya.kemungkinan pula dalam benak hati anak ada yang mampu untuk menjadi perannya.

\section{6) Langkah keenam: Tahapan diskusi dan Evaluasi}

Setelah langkah pemeranan telah selesai dilakukan, maka dalam tahapan ini guru bersama siswa mengadakan peninjauan kembali terhadap proses pembelajaran tadi. Kemungkinan masih banyak kekurangan-kekurangan dan kelemahan-kelemahan baik dalam sikap, emosional, maupun pentasnya. Apabila terjadi hal seperti ini maka guru harus mampu menjembatani siswa, agar tidak putus asa dan anak tetap termotivasi hingga jelas sasarannya. Pada saat diskusilah yang paling tepat untuk mengembangkan demokratis siswa. Apabila belum kena sasaran bagi pemeran tadi perlu adanya peran penggantinya, atau peran alternatif.

\section{7) Langkah ketujuh: Melakukan Pemeranan Ulang}

Pemeranan ini akan mempergunakan peran yang baru setelah ada pemilihan peran alternatif hasil diskusi.

\section{8) Langkah kedelapan: Melakukan dan Evaluasi tahap ke 2}

Dalam tahapan ini, seperti tahapan diskusi dan evaluasi pertama. Namun, kemungkinan pada tahapan ini permasalahn yang dihadapi agak ringan, yang nantinya dilanjutkan kepada evaluasi dan diskusi berikutnya hingga tujuan pembelajaran itu tuntas dan jelas dipahami oleh siswa.

\section{9) Langkah kesembilan: Membagi pengalaman dan menarik generalisasi}

Untuk dapat menyimpulkan tujuan yang hendak dicapai berdasarkan rencana pembelajaran awal, maka pada kesempatan ini siswa membagi pengalaman dalam peran yang mereka pernah lakukan. Tujuan ini untuk mengetahui sajauh mana empati mereka untuk menghadapi kenyataan yang mereka miliki sekarang. Di sini akan nampak dan beragam pengalaman yang nantinya akan memperjelas kenyataan yang sebenarnya tentang konsep, fakta, dan generalisasi sosial.

Penggunaan bermain peran tidak terlepas dari kegiatan tanya jawab dan evaluasi, keduanya sama pentingnya dengan apa yang sudah dijelaskan sebelumnya untuk peranainan yang memakai skrip. guru akan menemukan bahwa dengan bermain peran sangat membantu untuk peranainan, maka dari itu para pernain dan pengamat memiliki kesempatan untuk mereflesikan apa yang sedang terjadi. 
Suatu pembahasan tentang pentingnya tanya jawab setelah bermain peran memberikan beberapa kegunaan yang penting. Hal ini membantu para siswa mereflesikan dan mengkonsolidasikan pembelajaran mereka. Tanya jawab ini juga membantu para siswa mendapatkan pemahaman yang lebih baik dari peramainan peran tersebut sebagai strategi belajar mereka. Hal ini penting untuk memfokuskan bagianbagian terpisah dari tanya jawab pada para aktor dan para pengamat.

Untuk mendorong refleksi dari para aktor, guru bisa mengajukan pertanyaan-pertanyaan seperti yang tertera di bawah ini berdasarkan Brookfield dan Davis (Killen, 1998) sebagai berikut:

1) Apa yang membuat Anda senang dan khawatir dari permainan peran ini?

2) Seakurat apakah Anda dalam memprediksi aksi dan reaksi dari para pemain lain?

3) Apakah Anda pikir Anda bisa bereaksi lebih tepat terhadap aspek apapun dalam permainan peran tersebut?

4) Pendekatan lain apakah untuk memecahkan situasi yang mungkin sudah digunakan?

5) Menurut anda isu-isu apakah yang belum terpecahkan?

6) Apakah pendekatan-pendekatan lain untuk memecahkan isu-isu bisa lebih efektif, lebih realistis, atau lebih memuaskan bagi Anda?

7) Serealistis apakah situasi ketika permainan itu dimainkan?

8) Apa yang dirasakan ketika memainkan peran ini?

9) Bagaimana perasaan anda sekarang?

10) Menurut anda apa yang anda dapatkan dari permainan peran ini?

Guru bisa mengikutsertakan para pemeran juga para pengamat dalam mereflesikan pembelajaran mereka dengan meminta para pengamat untuk bertanya pada para aktor tentang aksi mereka, alasan dan asumsi mereka. Bermain peran dapat digunakan untuk melatih para siswa mengeksplorasi masalah-masalah hubungan manusia, serta untuk mengilustrasikan bagaimana bermain peran bisa digunakan untuk mengembangkan kemampuan dan mengeksplorasi perasaan, sikap, nilainilai, dan strategi pemecahan masalah.

Pemikiran baru dalam menggunakan bermain peran dalam sistem pembelajaran akan memberikan deskripsi pelajaran bermain setahap demi setahap termasuk panduan yang menjelaskan bermacam-macam peran, guru akan menemukan pelajaran ilmu pengetahuan yang lain yang lebih spesifik. Metode bermain peran pada umumnya diterapkan pada pembelajaran materi ilmu pegetahuan soaial pada topik yang berkaitan dengan sejarah, untuk memperjelas peristiwa-peristiwa yang terjadi masa 
lalu atau pada materi pembelajaran yang memerlukan peran untuk memperjelas topik yang dibahasnya.

\section{Aplikasi Model Role Playing Dalam Pembelajaran IPS Sebagai Upaya Pembelajaran Nilai di SD/MI}

Dalam bermain peran siswa terlebih dahulu harus mengetahui dan memahami informasi yang berkenaan dengan tujuan dan peran yang akan dimainkan. Untuk proses pemahaman itu, diskusi antaranggota kelompok dapat dilakukan. Tujuan yang umum tentu saja membangun simpati terhadap sesuatu nilai tetapi dalam hal ini nilai itu sudah harus dinyatakan secara lebih spesifik. Misalnya, nilai kerja sama dan kebersamaan yang mendasari perilaku kelompok social tertentu yang hidup di daerah terpencil. Bagi mereka ini keterasingan menyebabkan mereka harus berhadapan dengan berbagai masalah yang tidak mungkin dapat diselesaikan sendiri. Mereka tidak mungkin dapat mengolah tanahnya sendiri karena waktu yang tersedia, luasnya tanah yang ada, serta waktu yang relative cukup banyak. Oleh karena itu walaupun tindakan mereka mungkin tidak efisien, tidak produktif, tidak bersesuaian dengan kehidupan di kota di mana pemilikan pribadi sudah menjadi nilai yang dijunjung tinggi, tetapi apa yang mereka lakukan adalah sesuatu yang memang sesuai dengan lingkungan hidup yang ada.

Bermain peran model di atas adalah yang dinamakan Joyce dan Weil (1980:255) dengan istilah intergroup relations. Mengenai bentuk ini mereka mengatakan bahwa problema-problema yang muncul sebagai akibat hubungan kelompok yang berbeda etnis, ras, ataupun kelompok social dapat dipelajari lebih mendalam melalui proses belajar bermain peran. Perbedaan-perbedaan nilai antar kelompok itu mungkin saja disadari siswa tetapi mungkin juga tidak tetapi muncul dalam perkataan ataupun sikap sehari-hari.

Bermain peran dapat mengungkapkan nilai yang dianut kelompokkelompok itu dan dapat dikembangkan dari sesuatu yang menimbulkan reaksi negative menjadi sesuatu yang dapat menimbulkan penghargaan. Dalam mata pelajaran IPS permasalahan seperti ini banyak dijumpai dan bermain peran ini model ini dapat dilakukan. Dalam contoh lain misalkan, tujuan untuk memahami nilai yang dianut para pemuda, Bung Karno dan Bung Hatta dalam situasi di Jakarta Tahun 1945 setelah tanggal 15 Agustus, yang menyebabkan terjadinya peristiwa yang dikenal dengan nama Rengasdengklok.

Untuk menghidupkan kegiatan bermain peran (role playing) tersebut berbagai informasi yang berkenaan dengan situasi perjuangan kemerdakaan di Jakarta, pemerintah militer Jepang di Jakarta, semangat pemuda, dan cara/taktik perjuangan yang dipercayai Bung Karno dan Bung Hatta. Untuk hal semacam itu maka seorang siswa akan memainkan 
peran sebagai Bung Karno, yang lain sebagai Bung Hatta, yang lain lagi sebagai tokoh pemuda lain seperti Sukarni, Adam Malik, atau Subardjo, dan sebagainya.

Joyce dan Weil (1980:255) menyebut model bermain peran ini dengan istilah historical problems. Pemahaman terhadap nilai, informasi, ataupun situasi di mana peristiwa terjadi sangat penting dalam prosedur belajar bermain peran. Meskipun demikian, pemahaman itu tak perlu dilakukan untuk semua peran yang akan terlibat dalam kegiatan belajar bermain peran. Siswa dapat saja mendalami nilai dari tokoh/peran yang akan dimainkan tetapi hanya sekedar tahu mengenai nilai dari tokoh lainnya. Situasi yang demikian lebih menguntungkan jika yang akan dibangun adalah suasana seperti pada situasi yang melahirkan peristiwa Rengasdengklok. Dalam banyak situasi perbedaan nilai semacam itu terjadi dan ini adalah sesuatu yang merupakan realita hidup. Lagi pula, dengan hanya mendalami nilai dari peran yang dianut dan kurang memahami nilai yang dianut peran lainnya, maka proses mempertahankan nilai dari peran yang dimainkan akan tidak tercemari oleh pemahaman awal mengenai nilai yang dianut peran lain.

Bermain peran tidak hanya dapat dilakukan untuk suatu peristiwa yang sudah lampau, baik yang sudah lama atau pun yang baru beberapa tahun terjadi, tetapi dapat juga dilakukan untuk suatu peristiwa/kejadian yang masih hangat dalam masyarakat. Pengalaman belajar siswa ini dapat juga dikembangkan untuk peran sebagai tokoh ilmuwan tertentu dengan pandangan keilmuannya yang mungkin banyak dianut orang tetapi sudah tentu ada pula yang tidak menyenanginya. Untuk peran semacam itu tentu saja informasi mengenai apa yang didiskusikan akan sangat mendalam dan ini adalah keuntungan tambahan (nurturant effect). Misalkan siswa dapat memegang peran Adnan Buyung Nasution yang memiliki pandangan tertentu mengenai konstitusi Negara Republik Indonesia.

Dalam bermain peran semacam itu tentu saja siswa yang bersangkutan dapat pula berhadapan langsung dengan kelas/siswa di mana yang bersangkutan menjadi anggotanya. Misalnya, kelas sangat tidak sependapat dengan kebijaksanaan pemerintah/menteri tertentu dalam suatu persoalan politik tetentu. Untuk itu maka seseorang dapat bertindak sebagai menteri yang bersangkutan dibantu dnegan beberapa orang yang menjadi pembantu perumus kebijaksanaan. Tentu saja kelompok ini harus mencari informasi yang banyak berkaitan dengan kebijaksanaan yang dibicarakan serta pemahaman yang sangat tinggi tentang tujuan dan kebijaksanaan itu sendiri. Siswa yang menjadi menteri ditambah dengan kelompok pembuat keputusan tersebut akan berhadapan dengan siswa secara langsung. Siswa di kelas akan mengemukakan kritik mereka berdasarkan pandangan/nilai mereka sebagai siswa sedangkan siswa yang menjadi menteri dan kelompok pembantu akan menjelaskan 
berbagai masalah, nilai-nilai yang harus mereka perhatikan yang mungkin berbeda dari apa yang dianut siswa di kelas (dan dirinya sebagai anggota kelas). Dengan cara ini siswa tersebut dapat menyerap, memahami, dan menghargai nilai yang mendasari keputusan itu (walaupun tidak selalu harus diikuti dengan persetujuan terhadap nilai itu).

Siswa di kelas pun akan dapat mengembangkan penghargaan terhadap nilai tersebut. Selama ini mereka hanya akan membahas keputusan itu atau keputusan lain tanpa menyadari nilai yang lain dari apa yang mereka miliki. Pembahasan semacam itu tidak akan membantu siswa karena mereka tidak berhadapan dengan orang lain (dalam hal ini pembuat keputusan walaupun diperankan temannya sendiri). Melalui proses belajar bermain peran ada orang lain yang mencoba menjelaskan, mengemukakan, dan bahkan membela nilai-nilai yang dianut oleh pembuat keputusan.

Sesuatu yang perlu diperhatikan siswa dan guru dalam bermain peran ini adalah kesadaran bahwa mereka sedang belajar. Dalam kesadaran ini haruslah terdapat dua hal yang perlu mendapatkan kesadaran yang sungguh-sungguh. Pertama, dalam suatu proses belajar melalui bermain peran haruslah ada kesediaan untuk memahami dan mempelajari nilai yang dianut orang lain. Sikap ini penting, karena dari awal siswa sudah berketetapan tidak akan mengubah dirinya, apa pun yang akan terjadi, maka proses belajar bermain peran ini tidak akan mencapai tujuannya.

Kedua, mereka harus sadar bahwa temannya yang sedang bermain peran itu bukanlah musuhnya. Oleh karena itu, jika suatu proses belajar bermain peran sudah selesai, guru harus mengingatkan siswa agar mereka tetap bersahabat seperti biasa. Tindakan guru ini terutama penting untuk proses belajar bermain peran dalam bentuk terakhir di mana seorang atau beberapa siswa memegang peran (menjelaskan, mempertahankan nilai orang yang membuat keputusan) yang tidak disukai siswa di kelas. Jika seseorang tidak berhasil mengubah pandangannya dan juga nilai dirinya setelah proses belajar itu, ia tidak boleh dan tidak seharusnya membenci teman sekelasnya yang memegang peran itu seperti membenci orang yang diperaninya (Hasan, 1996).

Sebaliknya juga berlaku, siswa yang memegang peran tertentu yang mungkin saja kemudian setuju dengan nilai yang dipegang peran yang dimainkannya tidak boleh memperlakukan teman sekelas yang belum berubah pendiriannya dengan cara yang lain. Apalagi jika dalam diskusi dalam bermain peran itu terjadi silang pendapat yang serum aka guru harus dapat memperbaiki situasi yang terjadi dengan menyadarkan mereka bahwa mereka tidak boleh terbawa emosi tadi setelah diskusi selesai. Persoalan ini harus dijelaksan guru pada saat permulaaan suatu kegiatan bermain peran akan dilakukan. 


\section{E. Penutup}

Belajar merupakan kegiatan aktif siswa dalam membangun makna atau pemahaman terhadap suatu konsep, sehingga dalam proses pembelajaran siswa merupakan sentral kegiatan, pelaku utama dan guru hanya menciptakan suasana yang dapat mendorong timbulnya motivasi belajar pada siswa. Implementasi KTSP dalam proses pembelajaran menuntut adanya reorientasi pembelajaran yang konvensional. Reorientasi tidak hanya sebatas istilah "teaching" menjadi "learning", namun harus sampai pada operasional pelaksanaan pembelajaran.

Dalam kedudukan sebagai perancang dan pengembang kegiatan belajar, guru harus mampu menerapkan dan mengembangkan prinsipprinsip belajar dalam bentuk kegiatan belajar. Kegiatan-kebiatan belajar yang memungkinkan siswa aktif mengembangkan sikap, nilai, dan moral dalam dirinya dapat digunakan model bermain peran (role playing).

Model bermain peran (role playing) meliputi dua bentuk yaitu intergroup relations dan historical problems. Sesuatu yang perlu diperhatikan siswa dan guru dalam bermain peran ini adalah kesadaran bahwa mereka sedang belajar. Dalam kesadaran ini haruslah terdapat dua hal yang perlu mendapatkan kesadaran yang sungguh-sungguh. Pertama, dalam suatu proses belajar melalui bermain peran haruslah ada kesediaan untuk memahami dan mempelajari nilai yang dianut orang lain. Kedua, mereka harus sadar bahwa temannya yang sedang bermain peran itu bukanlah musuhnya. Oleh karena itu, jika suatu proses belajar bermain peran sudah selesai, guru harus mengingatkan siswa agar mereka tetap bersahabat seperti biasa.

\section{F. Daftar Pustaka}

Hasan, Hamid S. 1996. Pendidikan Ilmu-Ilmu Sosial. Jakarta: Depdikbud.

Joyce, B \& Weil, M. 1980. Models of Teaching. New York: Prentice Hall.

Killen, R. (1998). Effective Teaching Strategies. Australia; Social science Press.

Cecep Sumarna,,2005, Rekonstruksi Ilmu: Dari Empirik-Rasional Ateistik ke Empirik-Rasional Teistik, Bandung: Benang Merah Press

Mawardi Lubis, 2008, Evaluasi Pendidikan Nilai: Perkembangan Moral Keagamaan Mahasiswa PTAIN, Yogyakarta: Pustaka Pelajar. 